\title{
Suitability of fruits of selected blackcurrant (Ribes nigrum L.) cultivars for fresh market
}

\author{
Stanisław Pluta ${ }^{\mathrm{a}, *}$, Edward Żurawicz ${ }^{\mathrm{a}}$ and Kris Pruski ${ }^{\mathrm{b}}$ \\ ${ }^{a}$ Research Institute of Horticulture, Skierniewice, Poland \\ ${ }^{\mathrm{b}}$ Nova Scotia Agricultural College, Truro, NS, Canada
}

Received 31 January 2011; accepted 2 August 2011

\begin{abstract}
The fruit quality of 10 blackcurrant genotypes of Polish origin ('Bona', 'Gofert', 'Tines', D13B/11 and PC-425 very recently named as 'Tihope') and Ukrainian ('Chereshnieva', 'Yubylejnaia Kopania', 'Saniuta', 'Sofievskaia' and 'Vernisazh') was evaluated in Central Poland in 2008-2010. The yield, fruit size (weight of 100 berries), the length of strigs and number of berries per strig, fruit firmness, soluble solids, content of ascorbic acids (vit. C), fruit appearance, taste and aroma as well as the shelf-life of fresh fruit in a room temperature were assessed. Results obtained in studies showed that new Polish cultivars 'Tihope' (PC-425) and 'Gofert' as well as Ukrainian cultivars 'Jubilejnaja Kopania' and 'Vernisazh' were the most productive and had the highest average fruit yield. The largest fruits produced the Polish breeding clone (D13B/11). Large fruits also had the standard cultivar 'Bona', cv. 'Tihope' (PC-425) and 'Saniuta'. The highest number of fruit per strig was counted on Ukrainian cultivars ('Chereshnieva', 'Yubylejnaia Kopania', 'Saniuta') and Polish cv. 'Gofert'. These cultivars also produced the longest strigs. The tested cultivars differed slightly in the attractiveness of the fruits. 'Bona' and 'Tihope' (PC-425) boasted the best appearance of fruits. Fruits of 'Bona' were found as the most flavorful. 'Saniuta', 'Gofert' and D13B/11 demonstrated only a little less taste and aroma. The best shelf-life of fruits possessed 'Bona', 'Tihope' (PC-425) and 'Tines'. The firmest fruits were produced by 'Chereshnieva', 'Tihope' (PC-425), 'Sofievskaia' and 'Gofert'. The highest content of soluble solids was found in fruit of 'Gofert' and 'Tines'. The richest in vitamin C were fruits of 'Gofert', 'Sofievskaia' and 'Tihope' (PC-425).
\end{abstract}

Keywords: Blackcurrant, Ribes nigrum L., cultivars, dessert fruit quality, yield, fruit size, evaluation

\section{Introduction}

The blackcurrant (Ribes nigrum L.) is a commercially important small fruit crop extensively cultivated in Poland and several European countries. Due to the very high vitamin C content, high levels of polyphenols (flavonoids such as anthocyanins) and their nutritional properties, blackcurrants are considered of high medicinal value carrying numerous benefits to human health $[1-3,10,12]$. Fruits are used predominantly for the production of juice concentrate, syrups and as frozen fruit.

Recently in Western Europe countries such as Germany, Switzerland, The Netherlands, Belgium, United Kingdom and also in Poland there is a growing interest in fresh fruit consumption of black currants which, in turn, creates interest in cultivation of varieties suitable for the production of high quality fruit destined for fresh market. So called

*Corresponding author: S. Pluta, Research Institute of Horticulture, 96-100 Skierniewice, Pomologiczna 18, Poland. Tel.: +48 46 834 53 15; Fax: +48 4683332 28; E-mail: spluta@insad.pl. 
"dessert" cultivars should have large fruits (above $1.5 \mathrm{~g}$ ), good appearance, flavour and aroma, as well as should contain high amounts of nutraceuticals. The fruit should have good texture, be firm and arranged in long strigs that would ripen evenly.

An extensive applied breeding programme on new blackcurrant cultivars has been conducted at the Research Institute of Pomology and Floriculture (since January 2011 the Research Institute of Horticulture) in Skierniewice, Poland for a number of years.

The breeding work is also focused on the development of high quality fruit that would be meeting the requirements of a "dessert" cultivar. The research includes evaluation of existing varieties (both domestic and foreign) presently on the market, and the breeding programmes aiming at development of such new varieties.

The goal of the research presented in the paper was the evaluation of productivity, fruit quality and suitability of new black currant cultivars and breeding clones destined for fresh market consumption.

\section{Material and methodology}

\subsection{Plant material}

The research work was carried out on ten genotypes of black currants. The material was coming from different breeding programmes, different phenotypes and genotypes. The cultivars and clones coming from breeding at RIPF Skierniewice included: 'Bona', 'Gofert', 'Tines', D 13B/11 and the newest Polish cultivar 'Tihope' (PC-425). The cultivars coming from Ukraine included: 'Chereshnieva', 'Yubylejnaia Kopania', 'Saniuta', 'Sofievskaia' and 'Vernisazh'. Although all of the above cultivars and clones produce large and attractive fruits, the flavor and taste differ among them significantly. The known Polish cultivar 'Bona' was used as a standard. 'Bona' is a typical "dessert” cultivar which produces attractive, large and very tasty (sweet) fruits.

All fruit from plant material tested in this experiment was hand picked in a single harvest. Decision of fruit harvesting date was based on sensorial evaluation (visual maturity $-100 \%$ of black berries) and acceptable taste.

There was no abnormalities in the growth and development of bushes during all years of investigation, which means that blackcurrant plants received sufficient amount of chilling.

\subsection{Experimental design}

The experiment was established in the fruit orchard at RIPF Skierniewice (central Poland) in spring 2007. All plants were at the same age and the first data were collected in 2008 in the following year after planting. The Randomized Block Design with four replicates was used. Five plants (bushes) were planted in each replicate (plot) using spacing $3.5 \times 0.75 \mathrm{~m}$ with a $1.20 \mathrm{~m}$ space guard row between the plots. Research plots maintenance including pest control was performed according to standard recommendations for commercial production of black currants in Poland. Automatically controlled drip irrigation was installed in research plots.

\subsection{Data collection}

The research work was conducted in 2008-2010. The following data components were recorded: (i) growth rate of plants (the height and width of each plant [cm]), (ii) yield [kg/plot], (iii) size of fruit (weight of 100 berries [g]), (iv) number of berries in a strig and the length of the strig. The sensory analysis was also conducted: a panel of 12-15 people was evaluating the fruit appearance (visual attractiveness), flavor/aroma and taste of fresh fruit on the scale of 1-5 where 1 was the poorest and 5 was the best performance.

The shelf life of fresh fruit was also evaluated. These studies were carried out at room temperature, $18-20^{\circ} \mathrm{C}$, determining the condition/quality of the fresh fruit sample after 24 and $72 \mathrm{hrs}$.

Soluble solids content (Brix) in the fruit was determined with Rudolph J-157 refractometer. The vitamin C content ( $\mathrm{mg} / 100 \mathrm{ml}$ of juice) was measured with RQ-Easy reflectometer. The fruit firmness (in $\mathrm{N}$ ) was assessed using the INSTRON 5542 penetrometer. 


\subsection{Weather conditions}

During the study period 2008-2010, the weather conditions were different for each growing season. The 2008 growing season was rather warm with an average precipitation (within the long-term average). The 2009 and 2010 growing seasons were moderately warm but very rainy. In 2009, following the spring drought (until mid-May) the rainy period came lasting until the end of July.

The 2010 growing season was very similar to 2009 just the rainy period after spring drought was longer (until mid-August). The late frosts occurred in spring 2009 only $\left(-0.8\right.$ to $\left.-2.3^{\circ} \mathrm{C}\right)$ and affected yields in all black currant cultivars tested.

\subsection{Statistical analysis}

The results were analyzed (elaborated) statistically using the method of one-factor analysis of variance (ANOVA), according to the model of randomized block design. Significance of differences between means was evaluated using the Duncan's multiple test at $P=0.05$. Statistical variation in terms of differences between plots and years was not analyzed.

\section{Results and discussion}

The analyzed data pertaining to the evaluation of the black currant cultivars and breeding clones are shown in tables and figures below.

\subsection{Plant growth/vigour}

Table 1 illustrates growth (height/width and its ratio) and parentage of evaluated blackcurrant cultivars and clones. There were significant differences in growth observed between cultivars. Data were collected over the three growing seasons (2008-2010) and then the averages were calculated. Cultivars 'Tines', 'Vernisazh', 'Chereshnieva' and 'Tihope' (PC-425) produced the tallest plants $(111.3-124.7 \mathrm{~cm})$; the medium height bushes $(104.7-105.8 \mathrm{~cm})$ were observed with cultivars 'Gofert' and 'Yubylejnaia Kopania' (Table 1).

The remaining genotypes produced plants significantly shorter, below $97 \mathrm{~cm}$. The cultivar 'Tihope' (PC-425) produced the widest bushes $(184 \mathrm{~cm})$ followed by cultivars 'Chereshnieva', 'Tines', 'Yubylejnaia Kopania', 'Gofert' and 'Vernisazh'. The bushes having width below $126 \mathrm{~cm}$ were observed in the standard cultivar 'Bona' as well as in 'Sofievskaia', 'Saniuta' and in the clone D 13B/11. Similar observations related to the growth and vigour of a number of varieties ('Bona', 'Tines', 'Gofert', 'Yubylejnaia Kopania', 'Sofievskaia', 'Vernisazh') were made earlier $[4,5,9,14,15,19]$.

Besides the growth/vigour of the plants, the form/shape of the bushes is an important characteristic for the cultivar. We calculated the height/width ratio for each variety: values close to 1.0 indicate a ball shape of plants; values lower than 1.0 a spread form and values higher than 1.0 an erected form. All genotypes evaluated in this research were of a spread type with the cv. 'Tihope' (PC-425) producing the widest bushes (Table 1). Cultivars 'Vernisazh', 'Gofert' and 'Yubylejnaia Kopania' closely followed the 'Tihope' (PC-425). The average height to width ratio for these cultivars was $0.68-0.70$.

\subsection{Time of fruit ripening (average fruit harvest date)}

Table 2 shows the average date of ripening period for the fruit collected from the evaluated cultivars and clones. Values represent averages from three growing seasons, 2008-2010. Significant differences were observed between cultivars and clones and the harvest was extended to 8 days. Fruits of the standard cultivar 'Bona' and the clone $\mathrm{D} 13 \mathrm{~B} / 11$ were ripening the earliest, around July 7 th. The late ripening (July 15th) was observed with the cv. 'Tihope' (PC-425). 
Table 1

Country of origin, parentage and growth (height/width and its ratio) of evaluated blackcurrant cultivars/clones (Skierniewice, average from three seasons 2008-2010)

\begin{tabular}{|c|c|c|c|c|c|}
\hline \multirow[t]{2}{*}{ Cultivar/clone } & \multirow{2}{*}{$\begin{array}{l}\text { Country } \\
\text { of origin }\end{array}$} & \multirow[t]{2}{*}{ Parentage } & \multicolumn{2}{|c|}{ Plant growth $[\mathrm{cm}]$} & \multirow{2}{*}{$\begin{array}{l}\text { Height/ } \\
\text { width ratio* }\end{array}$} \\
\hline & & & Height & Width & \\
\hline 1. Bona & Poland & Ojebyn $\times(R$. dikuscha $\times$ Climax $)$ & $89.7 \mathrm{a}^{* *}$ & $115.7 \mathrm{ab}$ & 0.78 \\
\hline 2. Chereshnieva & Ukraine & $\begin{array}{l}{[(\text { R. nigrum } \times R \text {. petiolare }) \times[(\text { Yunost } \times \text { Zoya })} \\
\quad \times \text { Minaj Shmyrev }]] \times \text { Belorusskaya Sladkaya }\end{array}$ & $113.4 \mathrm{~d}$ & $139.8 \mathrm{~cd}$ & 0.81 \\
\hline 3. Yubylejnaia Kopania & Ukraine & Novost Prykarpatya $\times$ C-106 & $105.8 \mathrm{c}$ & $151.5 \mathrm{de}$ & 0.70 \\
\hline 4. Saniuta & Ukraine & $($ Yunost $\times$ Zoia $) \times$ Minaj Shmirev & $98.3 b$ & $120.9 b$ & 0.81 \\
\hline 5. Sofievskaia & Ukraine & Belorusskaya Sladkaya $\times$ C-106 & $88.6 \mathrm{a}$ & $103.1 \mathrm{a}$ & 0.86 \\
\hline 6. Vernisazh & Ukraine & Kloussonovskaya $\times$ Triton & $111.5 \mathrm{~d}$ & $160.7 \mathrm{e}$ & 0.68 \\
\hline 7. Gofert & Poland & Golubka $\times$ Fertodi-1 & $104.7 \mathrm{c}$ & $151.9 \mathrm{de}$ & 0.69 \\
\hline 8. Tines & Poland & Titania $\times$ Ben Nevis & $111.3 \mathrm{~d}$ & 146.6de & 0.76 \\
\hline 9. Tihope (PC-425) & Poland & Titania $\times$ P9/11/14 & $124.7 \mathrm{e}$ & $184.1 \mathrm{f}$ & 0.68 \\
\hline 10. D 13B/11 & Poland & Big Ben $\times$ Lentaj & $97.2 b$ & $126.3 \mathrm{bc}$ & 0.77 \\
\hline
\end{tabular}

*A Shape Factor of the Plant $=$ Height/Width Ratio; values close to 1.0 indicate a ball shape plant, values $<1.0$ spread shape, values $>1.0$ erected form. **Values within columns followed by the same letter do not differ significantly at $<0.05$ level.

Table 2

Harvest date and yield of the evaluated blackcurrant genotypes, Skierniewice 2008-2010

\begin{tabular}{|c|c|c|c|c|c|c|}
\hline \multirow[t]{2}{*}{ Cultivar/clone } & \multirow{2}{*}{$\begin{array}{l}\text { Harvest date } \\
2008-2010\end{array}$} & \multicolumn{5}{|c|}{ Fruit yield $[\mathrm{kg} / \mathrm{plot}]^{*}$} \\
\hline & & 2008 & 2009 & 2010 & $\Sigma$ Sum & Average \\
\hline 1. Bona & July 07 & $2.42 \mathrm{a}-\mathrm{d}$ & $1.38 \mathrm{a}$ & $5.57 \mathrm{a}$ & 9.37 & $3.12 \mathrm{a}$ \\
\hline 2. Chereshnieva & July 11 & $1.35 \mathrm{a}$ & $2.06 \mathrm{ab}$ & $6.98 \mathrm{a}$ & 10.39 & $3.46 \mathrm{ab}$ \\
\hline 3. Yubylejnaia K. & July 12 & $2.16 \mathrm{a}-\mathrm{c}$ & $5.72 \mathrm{c}$ & $13.69 \mathrm{c}$ & 21.56 & 7.19d \\
\hline 4. Saniuta & July 09 & $0.84 \mathrm{a}$ & $1.17 \mathrm{a}$ & $8.59 \mathrm{ab}$ & 10.59 & 3.53ab \\
\hline 5. Sofievskaia & July 11 & $1.50 \mathrm{a}$ & $1.64 \mathrm{ab}$ & $5.56 \mathrm{a}$ & 8.70 & $2.90 \mathrm{a}$ \\
\hline 6. Vernisazh & July 12 & $3.17 \mathrm{~b}-\mathrm{d}$ & $4.71 b c$ & $12.07 \mathrm{bc}$ & 19.95 & $6.65 d$ \\
\hline 7. Gofert & July 10 & $3.85 \mathrm{~d}$ & $4.76 \mathrm{bc}$ & $8.28 \mathrm{ab}$ & 16.88 & $5.63 \mathrm{~cd}$ \\
\hline 8. Tines & July 12 & $1.77 \mathrm{ab}$ & $5.79 \mathrm{c}$ & $7.31 \mathrm{ab}$ & 14.88 & $4.96 \mathrm{bc}$ \\
\hline 9. Tihope (PC-425) & July 15 & $3.98 \mathrm{~d}$ & $10.84 \mathrm{~d}$ & $13.81 \mathrm{c}$ & 28.63 & $9.54 \mathrm{e}$ \\
\hline 10. D 13B/11 & July 07 & $3.54 \mathrm{~cd}$ & $1.72 \mathrm{ab}$ & $5.77 \mathrm{a}$ & 11.03 & 3.68ab \\
\hline \multicolumn{2}{|c|}{ Average } & $2.46 a$ & $3.98 b$ & $8.76 c$ & - & - \\
\hline
\end{tabular}

*Values within columns followed by the same letter do not differ significantly at $<0.05$ level.

The medium time ripening of fruits (harvest July 9-12th) was observed with cvs 'Saniuta', 'Gofert', 'Sofievskaia', 'Chereshnieva', 'Yubylejnaia Kopania' and 'Tines'. A similar ripening term classification of selected black currant cultivars was reported in literature [6-9, 13, 15, 17-19].

\subsection{Fruit yield}

Harvest dates and the yield of evaluated blackcurrant clones and cultivars are shown in Table 2. The date of harvest is an average from three years observations. Yield of fruit (kg/plot) is shown for each year individually $(2008,2009$ and 2010) as well as the average for the three growing seasons (Table 2).

In 2010, the average fruit yield of evaluated blackcurrant cultivars and clones was significantly higher (2.2-3.5 fold) than in 2008 and 2009. This could be attributed to plants' age (each following year the plants were older and 
Table 3

Fruit size (mass of 100 fruits [g]), number and length of strigs of evaluated blackcurrant genotypes (Skierniewice, 2008-2010)

\begin{tabular}{|c|c|c|c|c|c|c|}
\hline \multirow[t]{3}{*}{ Cultivar/clone } & \multicolumn{4}{|c|}{ Mass of 100 fruits [g] } & \multirow{2}{*}{$\begin{array}{l}\text { Number of } \\
\text { fruits in strig }\end{array}$} & \multirow{3}{*}{$\begin{array}{l}\text { Length of } \\
\text { strig }[\mathrm{cm}]\end{array}$} \\
\hline & 2008 & 2009 & 2010 & Average & & \\
\hline & & & & & 2008-2010 & \\
\hline 1. Bona & $190.6 \mathrm{c} *$ & $169.0 \mathrm{~cd}$ & $142.6 \mathrm{e}$ & $167.4 \mathrm{e}$ & $4.8 \mathrm{a}$ & $5.4 \mathrm{ab}$ \\
\hline 2. Chereshnieva & $150.4 \mathrm{a}-\mathrm{c}$ & $120.3 \mathrm{a}$ & $96.7 \mathrm{ab}$ & $122.5 a-c$ & 13.0f & $8.6 f$ \\
\hline 3. Yubylejnaia K. & $155.4 \mathrm{a}-\mathrm{c}$ & $138.3 \mathrm{a}-\mathrm{c}$ & $116.1 b-d$ & $136.6 \mathrm{~b}-\mathrm{d}$ & $10.5 \mathrm{de}$ & $7.3 \mathrm{e}$ \\
\hline 4. Saniuta & $180.7 \mathrm{bc}$ & $137.5 \mathrm{a}-\mathrm{c}$ & $130.7 \mathrm{de}$ & 149.6de & $11.6 \mathrm{e}$ & 7.1de \\
\hline 5. Sofievskaia & $142.6 \mathrm{a}-\mathrm{c}$ & $113.9 \mathrm{a}$ & $122.1 \mathrm{c}-\mathrm{e}$ & $126.2 \mathrm{a}-\mathrm{d}$ & $9.4 \mathrm{~cd}$ & $6.4 \mathrm{~cd}$ \\
\hline 6. Vernisazh & $126.0 \mathrm{ab}$ & $112.3 \mathrm{a}$ & $106.4 a-c$ & 114.9ab & $9.7 \mathrm{~cd}$ & 7.0de \\
\hline 7. Gofert & $120.5 \mathrm{a}$ & $120.5 \mathrm{a}$ & $90.8 \mathrm{a}$ & $110.6 a$ & $10.3 \mathrm{~cd}$ & $7.3 \mathrm{e}$ \\
\hline 8. Tines & $131.2 \mathrm{ab}$ & $134.2 \mathrm{a}-\mathrm{c}$ & $117.4 b-d$ & $127.6 a-c$ & $7.8 \mathrm{~b}$ & $5.8 \mathrm{ac}$ \\
\hline 9. Tihope (PC-425) & $164.3 \mathrm{a}-\mathrm{c}$ & $158.3 \mathrm{~b}-\mathrm{d}$ & $127.4 \mathrm{c}-\mathrm{e}$ & 150.0de & $9.1 \mathrm{c}$ & $6.3 \mathrm{~cd}$ \\
\hline 10. D 13B/11 & $286.6 \mathrm{~d}$ & $182.6 \mathrm{~d}$ & $185.1 \mathrm{f}$ & 218.1f & $5.8 \mathrm{a}$ & $4.9 \mathrm{~b}$ \\
\hline Average & $164.8 c$ & $134.7 b$ & $123.5 a$ & - & - & - \\
\hline
\end{tabular}

*Values within columns followed by the same letter do not differ significantly at $<0.05$ level.

larger) and favorable weather conditions (lack of late spring frosts and high precipitation in 2010). Thus, the largest yield differences between tested genotypes were observed that year. The Polish genotypes proved to be the high yielders.

The average yield for the three years (2008-2010) was the highest in Polish cultivar 'Tihope' (PC-425) and cv. 'Yubylejnaia Kopania'. The Ukrainian cv. 'Vernisazh' and Polish 'Gofert' followed closely (Table 2). The average yields for the above were from $5.63 \mathrm{~kg} / \mathrm{plot}$ to $9.54 \mathrm{~kg} / \mathrm{plot}$ which were significantly higher than in the standard cultivar 'Bona', $3.12 \mathrm{~kg} / \mathrm{plot}$.

The lowest yields (2.90-3.68 kg/plot), comparable to the standard cultivar produced cvs 'Sofievskaia', 'Chereshnieva', 'Saniuta' and the clone D 13B/11. Gwozdecki [4] and Gwozdecki et al. [5] reported cv. 'Bona' producing significantly higher yields comparable to cvs 'Ojebyn' and 'Ben Lomond'. In Ukrainian trials, cultivars 'Sofievskaia', 'Yubylejnaia Kopania' and 'Vernisazh' produced the highest yields for five consecutive years, 1993-1998 [8]. Our data confirm these results.

\subsection{Fruit size}

Table 3 illustrates average (three growing seasons) fruit size expressed as weight ( $\mathrm{g}$ ) of 100 fruits and the length of strigs in evaluated blackcurrant genotypes. As expected, all genotypes were producing the largest fruits in 2008, the first growing season, when the plants were the youngest (Table 3). With time progressing and yield increasing, the fruits started becoming smaller. The standard cv. 'Bona' and the clone D13B/11 were producing the largest fruit in three consecutive growing seasons.

The average mass of 100 fruits for these genotypes was $167 \mathrm{~g}$ and $218 \mathrm{~g}$, respectively. Slightly smaller, not significantly different fruit were observed with the cv. 'Tihope' (PC-425) (150 g) and cv. 'Saniuta' (149 g). The remaining cultivars produced significantly smaller fruit (mass of 100 fruits was below $150 \mathrm{~g}$ ) than the above genotypes. In Serbia, Nikolić et al. [6] reported cv. 'Bona' producing the largest fruit in their experiments; the average weight of fruit was $2.36 \mathrm{~g}$ and was significantly higher than other tested cultivars 'Ben Lomond', 'Ben Nevis', 'Ben Sarek' and 'Titania'.

According to Kopań and Kopań [8] and Kopań et al. [9], Ukrainian cvs 'Chereshnieva', 'Yubylejnaia Kopania', 'Saniuta' 'Sofievskaia' and 'Vernisazh were producing large fruits, averaging $1.4 \mathrm{~g}$ to $3.5 \mathrm{~g}$. However, the results were obtained under Ukrainian soil and climatic conditions. Our experiments did not confirm these results. 
Table 4

Sensory analysis results and post-harvest "shelf-life" evaluation of blackcurrant genotypes for two growing seasons (Skierniewice, 2008-2009)

\begin{tabular}{lllllc}
\hline Cultivar/clone & Appearance* & Taste* & Aroma* & \multicolumn{2}{c}{ Post-harvest life** } \\
\cline { 5 - 6 } & & & & After 24 $\mathrm{h}$ & After 72 $\mathrm{h}$ \\
\hline 1. Bona & $4.6 \mathrm{~d}^{* * *}$ & $4.5 \mathrm{f}$ & $3.1 \mathrm{a}$ & 0.0 & 0.4 \\
2. Chereshnieva & $3.7 \mathrm{a}$ & $3.0 \mathrm{ab}$ & $3.6 \mathrm{bc}$ & 0.2 & 1.0 \\
3. Yubylejnaia K. & $3.8 \mathrm{a}$ & $3.4 \mathrm{a}-\mathrm{c}$ & $4.1 \mathrm{de}$ & 0.0 & 1.5 \\
4. Saniuta & $4.2 \mathrm{~b}-\mathrm{d}$ & $3.5 \mathrm{~b}-\mathrm{d}$ & $3.7 \mathrm{~b}-\mathrm{d}$ & 0.4 & 1.7 \\
5. Sofievskaia & $4.0 \mathrm{a}-\mathrm{c}$ & $3.0 \mathrm{a}$ & $4.1 \mathrm{de}$ & 0.7 & 1.2 \\
6. Vernisazh & $3.9 \mathrm{ab}$ & $3.3 \mathrm{a}-\mathrm{c}$ & $4.0 \mathrm{~d}$ & 0.0 & 2.4 \\
7. Gofert & $4.1 \mathrm{a}-\mathrm{c}$ & $4.1 \mathrm{ef}$ & $3.5 \mathrm{~b}$ & 0.0 & 2.5 \\
8. Tines & $4.3 \mathrm{~cd}$ & $3.4 \mathrm{a}-\mathrm{c}$ & $3.9 \mathrm{~cd}$ & 0.0 & 0.9 \\
9. Tihope (PC-425) & $4.2 \mathrm{~b}-\mathrm{d}$ & $3.5 \mathrm{~cd}$ & $4.4 \mathrm{e}$ & 0.0 & 0.7 \\
10. D 13B/11 & $4.4 \mathrm{~cd}$ & $4.0 \mathrm{ef}$ & $3.4 \mathrm{~b}$ & 1.0 & 4.3 \\
\hline
\end{tabular}

*evaluation scale $1-5 ; 1$ - the lowest/poorest value, 5 - the highest/the best value.

**post-harvest value ("shelf-life"); evaluation based on the number of decomposed/rotten fruit from a random sample of 100 fruits in 3 replicates.

***Values within columns followed by the same letter do not differ significantly at $<0.05$ level.

\subsection{Number of fruits per strig and length of strigs}

Data in Table 3 also presents fruit characteristics of evaluated blackcurrant genotypes. The highest average number of fruits in strigs (11.6-13.0) was recorded with the Ukrainian cvs 'Saniuta' i 'Chereshnieva' during the three 2008-2010 growing seasons. The majority of tested cultivars had from 7.8 to 10.5 fruits in a strig. The standard cv. 'Bona' and the clone D13B/11 produced the lowest number of fruit per strig (Table 3). These two genotypes had also the shortest strigs, $4.9 \mathrm{~cm}$ and $5.5 \mathrm{~cm}$ respectively.

The longest strigs were observed in Ukrainian cvs 'Chereshnieva', 'Yubylejnaia Kopania', 'Vernisazh' and 'Saniuta' as well as in a Polish cv. 'Gofert'. The length of strigs varied from $7.0 \mathrm{~cm}$ to $8.6 \mathrm{~cm}$ in these cultivars and it differ significantly from the strig length of cv. 'Bona' (Table 3). The remaining cultivars were producing medium length strigs of 5.8-6.4 cm, which were more difficult to harvest than from cultivars producing longer strigs. Our observations indicated that blackcurrant berries on long strigs were more attractive for the fresh market.

\subsection{Sensory evaluation and post-harvest shelf life of fruits}

The results of sensory analysis of fresh fruits are presented in Table 4. The sensory panel consisted of 12-15 not trained testers/panelists (employees of the Fruit Plant Breeding Department of the Institute). All three tested variables (appearance, taste and aroma/flavor) were significantly different in all of the evaluated cultivars and clones. Although the fruit appearance of genotypes did not differ to a larger extent, the fruit of the standard cv. 'Bona' and the clone D13B/11 seemed the most attractive to the panelists (Table 4).

Fruits of cv. 'Bona' were found the best tasting among all of the genotypes tested, as they did not have a strong "blackcurrant" aroma that often is disliked by consumers. The high "dessert value" of cv. 'Bona' fruit is well known and was previously reported [5, 15-18]. The Ukrainian cv. 'Saniuta', the Polish cv. 'Gofert' and the clone D13B/11 closely followed cv. 'Bona' as the best tasting fruit (Table 4).

The high value of the Polish cv. 'Bona' fruit (as best tasting) was also reported in Serbia [11]. Kopań and Kopań [8] and Kopań et al. [9] reported a good taste of fresh fruit and processed jams and jellies for Ukrainian blackcurrant cultivars. With regards to post-harvest characteristics, our studies have shown that the fruit of cvs 'Bona', 'Tihope' (PC-425) and 'Tines' had the longest "shelf life" when kept at room temperature for 72 hours (Table 4). 


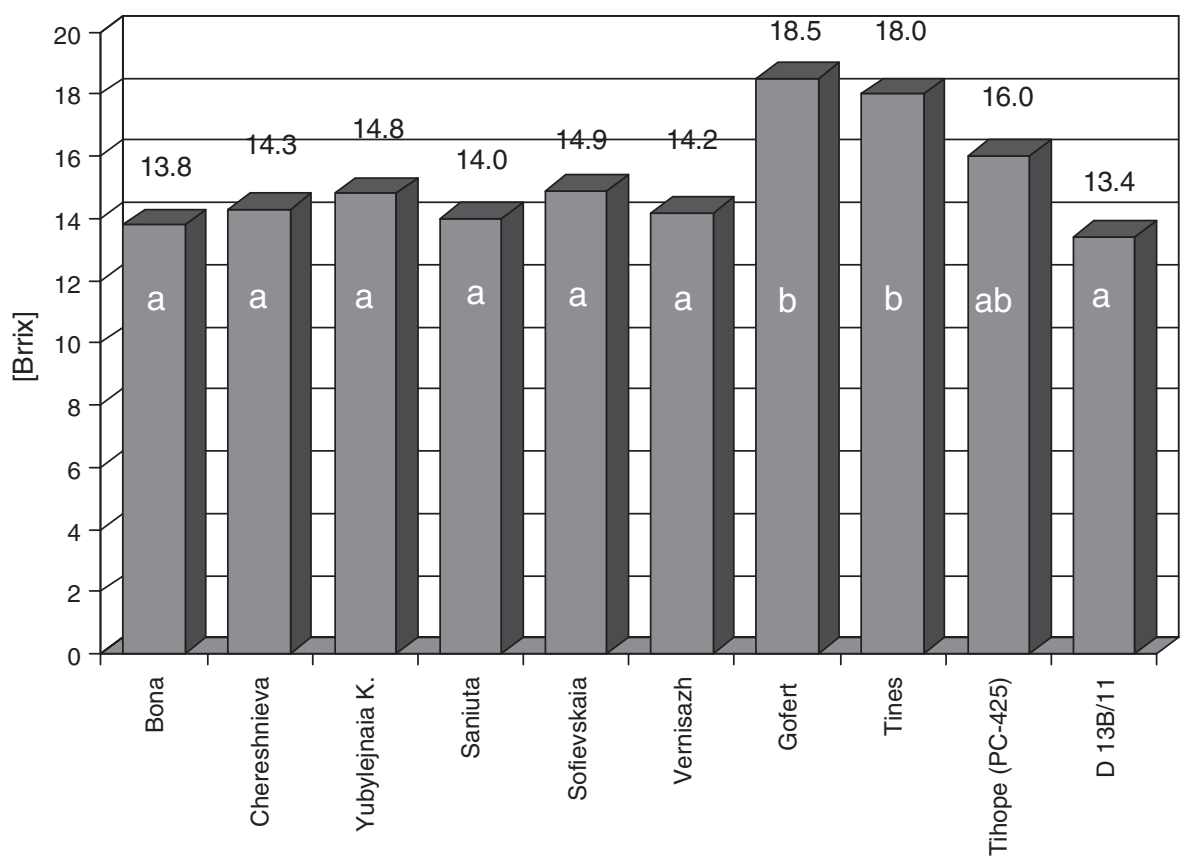

Fig. 1. Soluble solids content in fruits of evaluated blackcurrant genotypes (Skierniewice, average from 2008-2009).

\subsection{Quality and firmness of fruits}

The highest amounts of juice extract/soluble solids ( ${ }^{\circ}$ Brix) were found in fruits of Polish cultivars 'Gofert' $(18.5 \%)$ and 'Tines' (18.0\%). Fruits of other cultivars contained significantly less soluble solids (Fig. 1). The levels varied from $13.4 \%$ in clone D13B/11 to 16.0\% in 'Tihope' (PC-425) and did not differ significantly from each other.

The highest vitamin C content was recorded for fruits of the new Polish cultivar 'Gofert' (150 mg/100 ml), Ukrainian cv. 'Sofievskaia' $(127 \mathrm{mg} / 100 \mathrm{ml})$ and the Polish cultivar 'Tihope' (PC-425) (127 mg/100 ml), (Fig. 2). In other cultivars, the vitamin C content was significantly lower, $80-100 \mathrm{mg} / 100 \mathrm{ml}$.

Chemical analyses of fruit (sugar content, organic acids including ascorbic acid (vitamin C), pectins and phenols) for Ukrainian cultivars 'Chereshnieva', 'Yubylejnaia Kopania', 'Saniuta', 'Sofievskaia' and 'Vernisazh' were also reported in Kopań and Kopań [8] and Kopań et al. [9] work. According to their data, the above mentioned cultivars contained high amounts of bioactive compounds such as phenols and ascorbic acid (vitamin $\mathrm{C}$ ).

The fruits produced by cv. 'Chereshnieva' and 'Tihope' (PC-425) were the firmest, 5.0 N and 4.4 N respectively (Fig. 3). Quite firm were also fruits of cvs. 'Sofievskaia' and 'Gofert' (3.7N). Fruits of the other cultivars were significantly less firm and did not differ from each other.

\section{Conclusions}

Blackcurrant cultivars studied under conditions of Central Poland differ between each other with regards to evaluated characteristics (variables).

1. The most vigorous growth is observed with 'cvs. Tihope' (PC-425), 'Tines', 'Yubylejnaia Kopania', 'Chereshnieva' and 'Vernisazh'. The lowest vigour possesses the standard cv. 'Bona'.

2. The newest Polish cultivar 'Tihope' (PC-425) and Ukrainian cv. 'Yubylejnaia Kopania' produce the highest yields. 


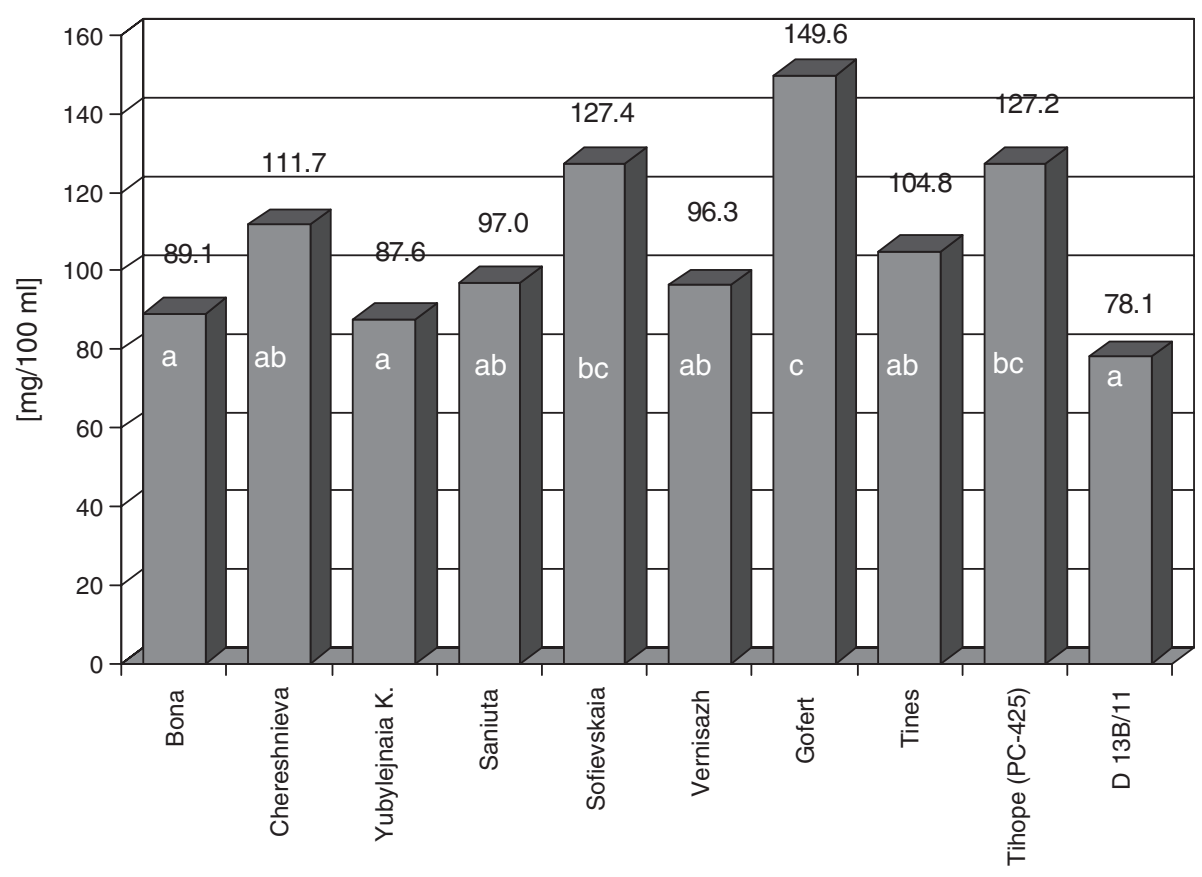

Fig. 2. Vitamin C content in fruits of evaluated blackcurrant genotypes (Skierniewice, average from 2008-2009).

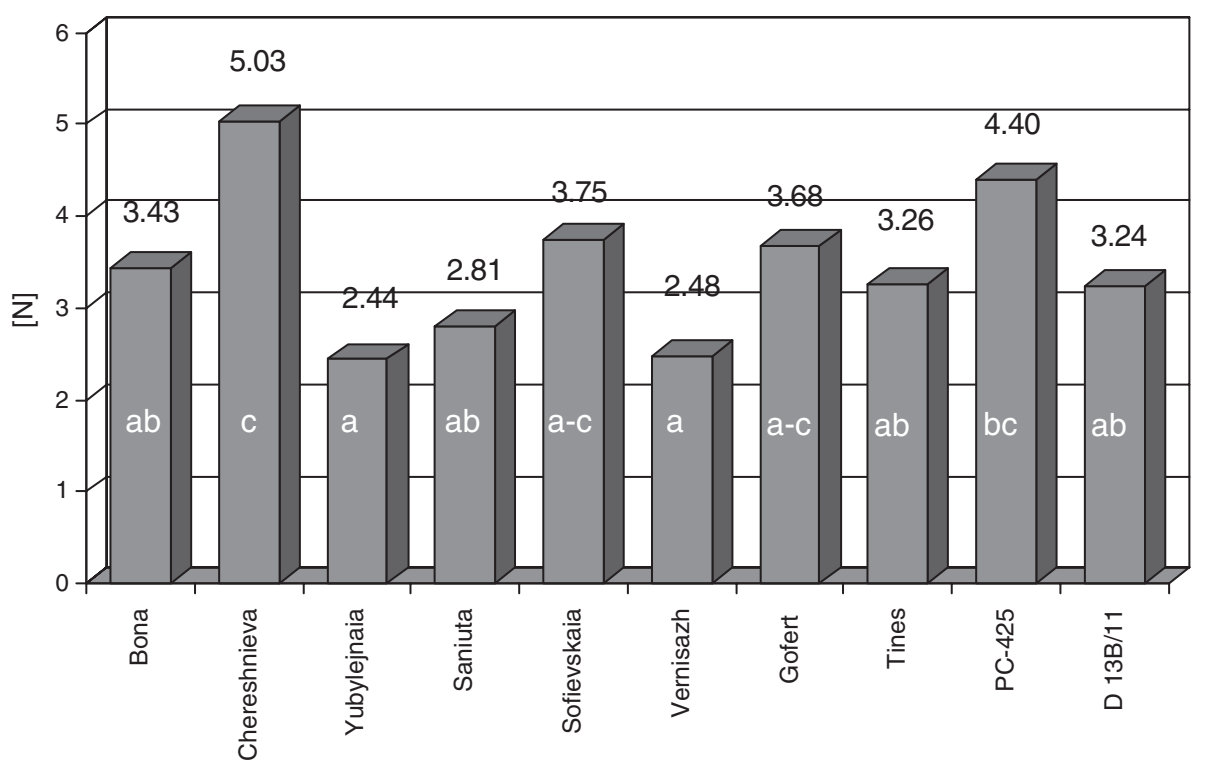

Fig. 3. Firmness of evaluated blackcurrant genotypes (Skierniewice, average from 2008-2009).

3. The largest fruits are produced by genotypes coming from the Polish breeding programme such as clone D13B/11, the newest cv. 'Tihope' (PC-425) and cv. 'Bona'. The Ukrainian cultivar 'Saniuta' also produces fruit in the above category.

4. The best appearance, taste and fruit aroma is associated with cultivars 'Bona', 'Gofert', 'Tihope' (PC-425) and clone D 13B/11. 
5. Fruits of cultivars 'Bona', 'Tihope' (PC-425), 'Tines' and 'Chereshnieva' show good ability for short term storage. 'Chereshnieva' and 'Tihope' (PC-425) produce also the most firm fruits.

6. The highest soluble solids content have fruits of cultivar 'Gofert', 'Tines' and 'Tihope' (PC-425).

7. The genotypes 'Gofert', 'Sofievskaia' and 'Tihope' (PC-425) have also the highest vitamin C content among tested cultivars.

\section{References}

[1] R.M. Brennan, Currants and gooseberries. In: J.F. Hancock (ed.) Temperate fruit crop breeding, Springer, Berlin, (2008), 177-196.

[2] R.M. Brennan and J. Graham, Improving fruit quality in Ribes and Rubus through breeding, Funct Plant Sci Biotechnol 3 (2009), $22-29$.

[3] N. Deighton, D. Stewart, H.V. Davies, P.T. Gardner, G.G. Duthie, W. Mullen and A. Crozier, Small fruit as sources of dietary antioxidants, Atca Hort 585(2) (2002), 459-465.

[4] J. Gwozdecki, Two new black currant cultivars, Acta Hort 352 (1993), 325-328.

[5] J. Gwozdecki, D. Chlebowska and K., Pierzga, Ocena owocowania dwóch polskich odmian porzeczki czarnej, Zesz Nauk Inst Sad Kwiac 10 (2002), 119-124.

[6] A.V. Isaczkin, B.N. Vorobiev and O.N. Aladina, Sortovoj katalog, Jagodnyje kultury, EKSMO - Press, "Lik" Press, 2001.

[7] V.P. Kopań, Atlas perspektivnych sortov plodovych i jagodnych kultur Ukrainy, Pod red, V.P. Kopaá Kijew, OOO “Odeks”, 1999 , s. 454.

[8] V.P. Kopań and K.N. Kopań, Rezultaty hodowli odmian na Ukrainie, IX Spotkanie Sadownicze, Sandomierz 2000 (2000), 83-91.

[9] V.P. Kopań, K.N. Kopań and A. Yareshchenko, The genus Ribes: New cultivars of intensive type obtained in Ukraine, Sadovodstvo Vinogradarstvo 6 (2003), 17-21.

[10] C.E. Lister, P.E. Wilson, K.H. Sutton and S.C. Morrison, Understanding the health benefits of blackcurrants, Atca Horticulturae 585(2) (2002), 443-449.

[11] M. Nikolić, T. Vulić, J. Milivojević and B. Dordević, Pomological characteristics of newly introduced Black currant cultivars (Ribes nigrum L.). Material from the International Conference "Perspectives in European fruit Growing", Hortuicultural Faculty in Lednice, $C z e c h$ Rep (2006), 200-220.

[12] G.J. McDougall, H.A. Ross, M. Ikeji and D. Stewart, Berry extracts exert different antiproliferative effects against cervical and colon cancer cells grown in vitro, J Agric Food Chem 56 (2008), 3016-3023.

[13] S. Pluta, Zeszyty Pomologiczne. Porzeczki i agrest, Wyd ISK Skierniewice, 1996.

[14] S. Pluta and E. Żurawicz, 'Ores', 'Ruben' i ‘Tines' - nowe polskie odmiany porzeczki czarnej dla integrowanej produkcji owoców. XI Ogólnopolski Naukowy Zjazd Hodowców Roślin Ogrodniczych nt. "Naturalna i indukowana zmienność w genetycznym doskonaleniu roślin ogrodniczych", Monografia, 2007, 99-10.

[15] S. Pluta and E. Żurawicz, Deserowe odmiany - nowy cel programu hodowli porzeczki czarnej w Instytucie Sadownictwa i Kwiaciarstwa w Skierniewicach, Materiały z XLV Ogólnopolska Naukowa Konferencja Sadownicza, Skierniewice, August 28-29, (2008), 12-15.

[16] S. Pluta and E. Żurawicz, The last twenty years of blackcurrant (Ribes nigrum L.) breeding work in Poland. Acta Hort 814 ( 2009a), 309-314.

[17] S. Pluta and E. Żurawicz, Dessert type cultivars of blackcurrant (Ribes nigrum L.) - new breeding aim at the RIPF, Skierniewice, Poland. "National Small Fruit Conference" w Dandong, Liaoning Province, China. Journal of Jilin Agricultural University, 2009-10, 31(5) (2009b), $481-485$.

[18] Pomologia odmianoznawstwo roślin sadowniczych - aneks. Porzeczka czarna. Porzeczka czerwona. Agrest. Praca zbiorowa pod red. E. Żurawicza, PWRiL, Warszawa, 2003,165-173; 175-180; 182-188.

[19] E. Żurawicz and S. Pluta, Perspektywy hodowli nowych deserowych odmian porzeczki czarnej w Polsce. Konferencja Naukowa nt. "Ogrodnictwo jutra - wyzwania i zagrożenia”, Kraków, (2009), 209-210. 